\author{
M. Chasapis, D. A. Samaras, K. Theodoropoulos \& E. Eleftheriadou
}

\title{
The vascular flora of Mt Tzena (northern Greece)
}

\begin{abstract}
Chasapis, M., Samaras, D. A., Theodoropoulos, K. \& Eleftheriadou, E.: The vascular flora of Mt Tzena (northern Greece). - Fl. Medit. 30: 55-63. 2020. — ISSN: 1120-4052 printed, 22404538 online.

Mt Tzena is located in the northernmost part of North-Central Greece. A first floristic inventory of the mountain is presented based on an intensive field collection and literature records. The vascular flora of the study area consists of 1254 specific and subspecific taxa out of which 858 taxa are reported for the first time.
\end{abstract}

Key words: vascular plants, floristic inventory, Tzena mountain, Balkans.

\section{Introduction}

Mt Tzena presents a phytogeographical interest due to its geographical position and habitat richness. Nevertheless, the flora of the mountain was almost unknown until the seventies, like many other mountains along the northern borders of Greece, due to their poor accessibility. The botanical exploration of Mt Tzena started in the seventies and eighties with the Mountain Flora of Greece project (Strid \& Papanikolaou 1981; Strid \& Franzen 1982; Strid 1986; Strid \& Tan 1991). A total number of 155 taxa were published in these works, mainly from the high altitudes of Mt Tzena. Other floristic contributions, not related with the above mentioned project, were those of Melzheimer \& Greuter (1979) and Voliotis $(1983,1986)$ with the latter mentioning the presence of 170 taxa from Mt Tzena. In the two first volumes of Flora Hellenica (Strid \& Tan 1997, 2002) 86 taxa were reported from Mt Tzena. Several other floristic reports from the Greek part of Mt Tzena have been published more recently by Tiniakou (1991), Schuler (2004), Parent (2005), Kučera \& al. (2006), Tan \& al. (2006), Biel \& Tan (2008), Font \& al. (2009), Gottschlich \& Schuler (2011), Gonzalo-Estébanez (2013) and Chasapis \& al. (2019). Despite the extensive collections during the last 5 decades from the mountains of northern Greece, the flora of Mt Tzena remains poorly known, with only 396 literature reports.

This study tries to fill the gap in knowledge of the incompletely known flora of Mt Tzena by presenting a complete catalogue of all vascular plants currently known from the mountain. A detailed floristic analysis is also being presented with a focus on the endemic and range-restricted plants. 


\section{Materials and methods}

Study area - Mt Tzena is located in North-Central Greece, $83 \mathrm{~km}$ from the city of Thessaloniki. The mountain lies between $41^{\circ} 06^{\prime}$ and $41^{\circ} 11^{\prime} \mathrm{N}$ of latitude and $22^{\circ} 10^{\prime}$ and $22^{\circ} 18^{\prime} \mathrm{E}$ of longitude, and covers an area of 5,327 ha that ranges from 600 to $2182 \mathrm{~m}$ in elevation (Fig. 1). The study area is restricted among the borders between Greece and North Macedonia to the north, the stream "Katharo" to the west, the plateau "Notias" to the south and the forest road that connects "Perikleia" with the military outpost "Tagmatarchis Vasileios Papagiannis" to the east.

Metamorphic rocks (mainly schist and marble) dominate in the study area. A variety of sedimentary rocks (sandstone, limestone, travertine) and igneous rocks (andesite, dacite, trachyte etc.) can be also found (Mauridis \& al. 1982; Galeos \& al. 1996). Only the lowest elevational zone of Mt Tzena has a Mediterranean climate with wet, mild winters and dry, warm summers (Chasapis 2017). At mid- and high altitudes the climate is humid continental with Mediterranean influence (dry and warm summers). According to Köppen climatic classification, the lower elevations belong to the Csb type (Chasapis 2017), while the mid- and higher to the Dsb type (Beck \& al. 2018). The highest elevational zone, above $1800 \mathrm{~m}$, has no dry season and, therefore, belongs to the $\mathrm{Dfb}$ and $\mathrm{Dfc}$ types (Chasapis 2017; Beck \& al. 2018).

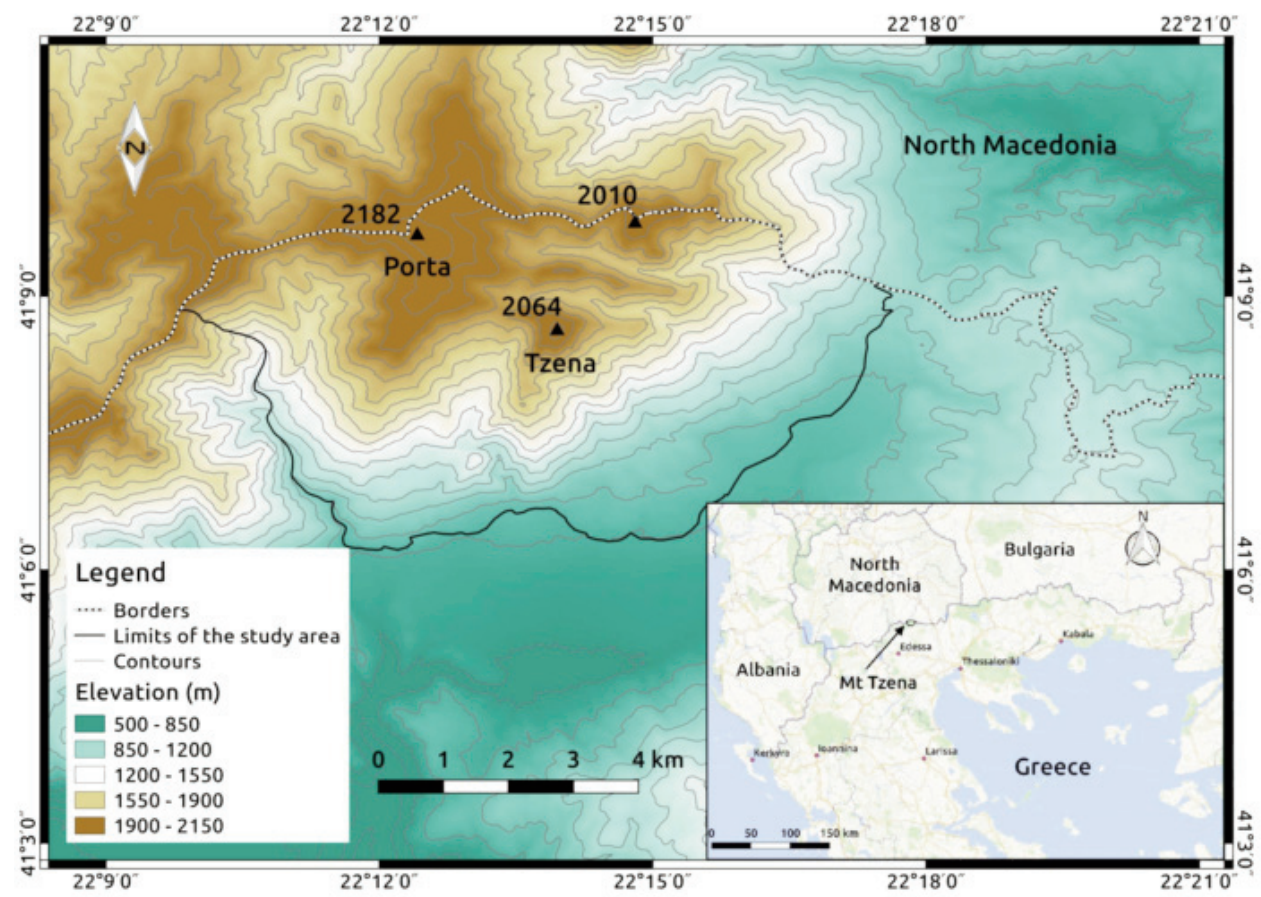

Fig. 1. Map of the study area. 
Woods of deciduous broad-leaved tree species occupy more than $50 \%$ of the mountain area, extending to the altitude of $1800 \mathrm{~m}$ (Chasapis \& al. 2013). The most common among them are the beech forests (Carpino-Fagetea sylvaticae), followed by thermophilous deciduous forests (Quercetea pubescentis). Beech forests are distinguished in three types: the acidophilous beech forests of the Luzulo-Fagion sylvaticae alliance, the mesic beech forests of the Galio odorati-Fagion sylvaticae and the thermophilous beech forests of the Cephalanthero-Fagion sylvaticae (Chasapis 2017). Thermophilous deciduous forests are distinguished in two types: the forests of Quercus frainetto Ten. (Quercion confertae) that appear in the east part of the study area on siliceous rocks, and the mixed forests of $Q$. pubescens Willd., Ostrya carpinifolia Scop. and Carpinus orientalis Mill. (Fraxino orniOstryion) that appear in the south-west and south-central part of the study area on calcareous rocks (Chasapis 2017).

The second most extended vegetation type of Mt Tzena is the dry grasslands (FestucoBrometea) that occupy $24 \%$ of the study area. Azonal vegetation appears along streams at low altitudes $(<750 \mathrm{~m})$. The riparian vegetation consists mainly of the tree species Platanus orientalis L. and Alnus glutinosa (L.) Gaertn., with the presence of several willow species (Salix alba L., S. eleagnos Scop. and S. purpurea L.). Above the timberline the heaths of Juniperus communis subsp. nana Syme are the dominant vegetation type.

Data collection and analysis - The floristic catalogue (Electronic Supplementary File 1 ) is based on collections and field observations carried out by the first author during spring, summer and autumn of 2009-2014. Published records are also included in the catalogue. Plant specimens that were collected in the field are stored in the herbarium of the Laboratory of Forest Botany-Geobotany, in the Aristotle University of Thessaloniki, Greece (TAUF). Plant identification was based on the main national and European Floras (Jordanov \& al. 1963-1995; Tutin \& al. 1968-1980, 1993; Pignatti 1982; Strid 1986; Strid \& Tan 1991, 1997, 2002) and selected taxonomic literature (Zohary \& Heller 1984; Snogerup \& Snogerup 2001; Bancheva \& Raimondo 2003). The nomenclature follows Dimopoulos \& al. (2013, 2016). Families, genera, species and subspecies are arranged alphabetically within the four main taxonomic groups: Pteridophyta, Gymnospermae, Dicotyledoneae and Monocotyledoneae. The definitions of species and taxa, as taxonomic ranks, follow Dimopoulos \& al. (2016). Life-form categories of taxa are coded according to Raunkiaer's classification system as was modified by Dimopoulos \& al. (2013). Life-form sub-categories are according to the classification system of Ellenberg \& Mueller-Dombois (1967) as was modified by Pignatti (1982). Chorological types of taxa are based on the system established for the checklist of vascular plants of Greece (Dimopoulos \& al. 2013).

\section{Results \& Discussion}

Floristic analysis - The vascular flora of Mt Tzena consists of 1254 taxa, belonging to 102 families and 466 genera (Table 1). The total number of taxa is composed of 268 subspecies, 981 species that have no subspecies and 5 species of Taraxacum identified at section level. From these, 858 taxa ( $68.4 \%$ of the total flora) are reported for the first time. From the remainder 396 literature references, 356 taxa were either collected or observed 
Table 1. Numbers of plant families, genera, species, subspecies and taxa in the three main taxonomic groups of the vascular flora of Mt. Tzena.

\begin{tabular}{lccccc}
\hline & Families & Genera & Species $^{\mathbf{1}}$ & Subspecies & Taxa $^{\mathbf{2}}$ \\
\hline Pteridophytes & 9 & 13 & 24 & 2 & 25 \\
Gymnosperms & 4 & 5 & 10 & 5 & 11 \\
Angiosperms & 89 & 448 & 1176 & 261 & 1218 \\
Total & $\mathbf{1 0 2}$ & $\mathbf{4 6 6}$ & $\mathbf{1 2 1 0}$ & $\mathbf{2 6 8}$ & $\mathbf{1 2 5 4}$ \\
\hline
\end{tabular}

1. are comprised of (a) species that have no subspecies and (b) species that have one or more subspecies 2. include 5 species of Taraxacum identified at the Section level.

by the first author, while 40 references could not be confirmed. Fifteen (15) additional taxa that have been reported from Mt Tzena but their presence in NC Greece has not been confirmed, were excluded from the floristic analysis. The presence of these 15 taxa in the study area is doubtful, therefore are noted in the floristic catalogue with a question-mark (?). Additionally, 4 hybrids are mentioned in the floristic catalogue but have been disregarded from the floristic analysis. Mt Tzena, despite its small area, presents a high diversity in vascular plants. This can be attributed to the broad elevation range of the mountain $(600-2182 \mathrm{~m})$, together with its habitat richness and geographical position. NC Greece has been recognised as a floristic region of high diversity (Dimopoulos \& al. 2013; Strid \& Tan 2017).

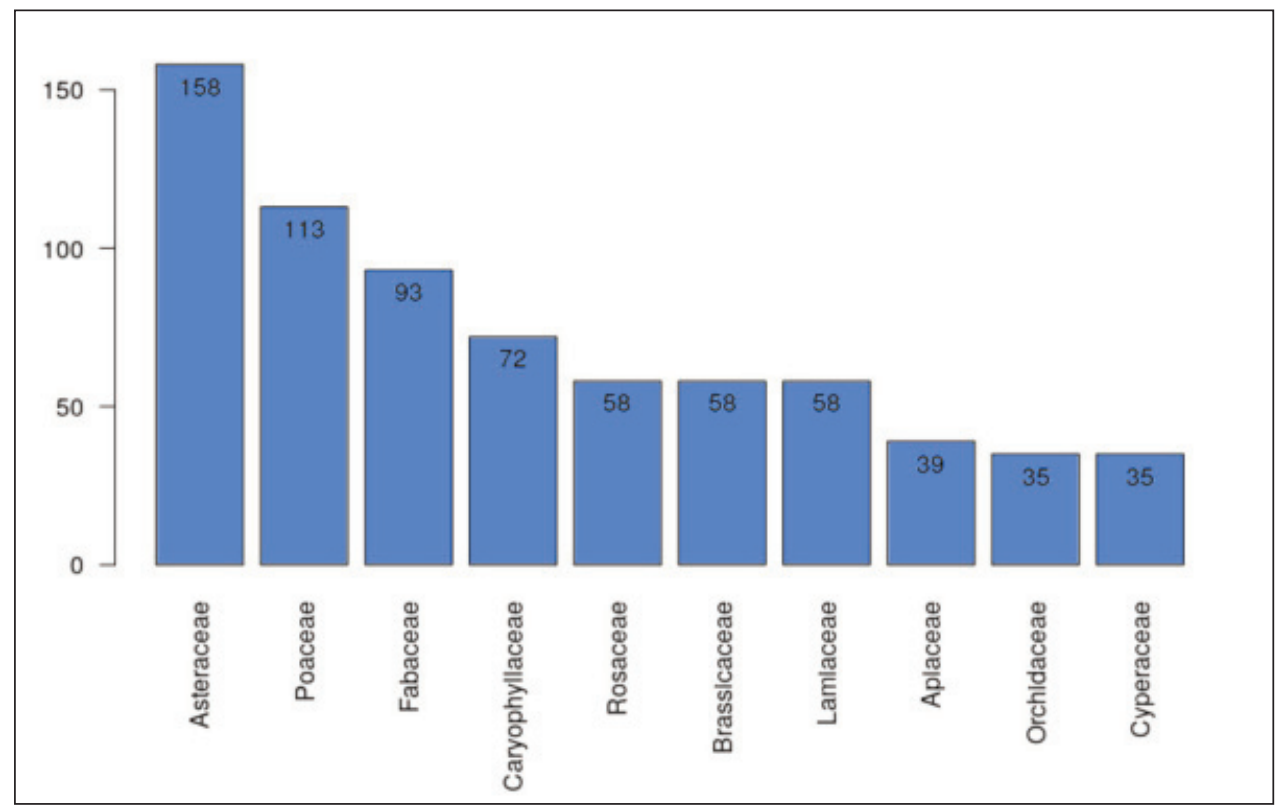

Fig. 2. The ten most taxa-rich families of the vascular flora of Mt Tzena. 
The ten most taxa-rich families together include 719 taxa, representing the $57.3 \%$ of the total flora of Mt Tzena (Fig. 2). The 4 most taxa-rich families are Asteraceae, Poaceae, Fabaceae and Caryophyllaceae with 158, 113, 93 and 72 taxa, respectively (Fig. 2). These four families are consistently the richest in number of taxa, for several high Greek mountains (Dimitrellos \& Christodoulakis 1995, Vlachos \& al. 2009) and for the Greek flora in general (Dimopoulos \& al. 2013). Two other families, Rosaceae and Cyperaceae, are of significant interest (Fig. 2). The family of Rosaceae is the $5^{\text {th }}$ richest in number of taxa, which reflects the transitional geographic position of Mt Tzena between the Mediterranean and continental areas. The family of Cyperaceae is exceptionally rich in number of taxa (35 taxa), most of which belong to the genus Carex. The richness of the family can be attributed to the presence of various hydrophilous plant communities, especially the subalpine calcium-rich fens.

Spectra-Hemicryptophytes and therophytes are the most abundant plant life forms in the flora of Mt Tzena with a proportion of $52.0 \%$ and $20.8 \%$ respectively (Fig. 3). Geophytes and phanerophytes follow with $13.3 \%$ and $8.5 \%$ respectively, while chamaephytes are the less abundant $(5.4 \%)$. The most abundant chorological group of plants are the Widespread taxa (634 taxa - 50.76\%), followed by the Mediterranean (326 taxa $26.10 \%)$ and Balkan taxa (275 taxa - $22.02 \%)$ (Table 2). The proportion of Greek endemics and Aliens is much lower (0.56 \%). According to Emberger (1967), hemicryptophytes characterize the temperate climatic zone.

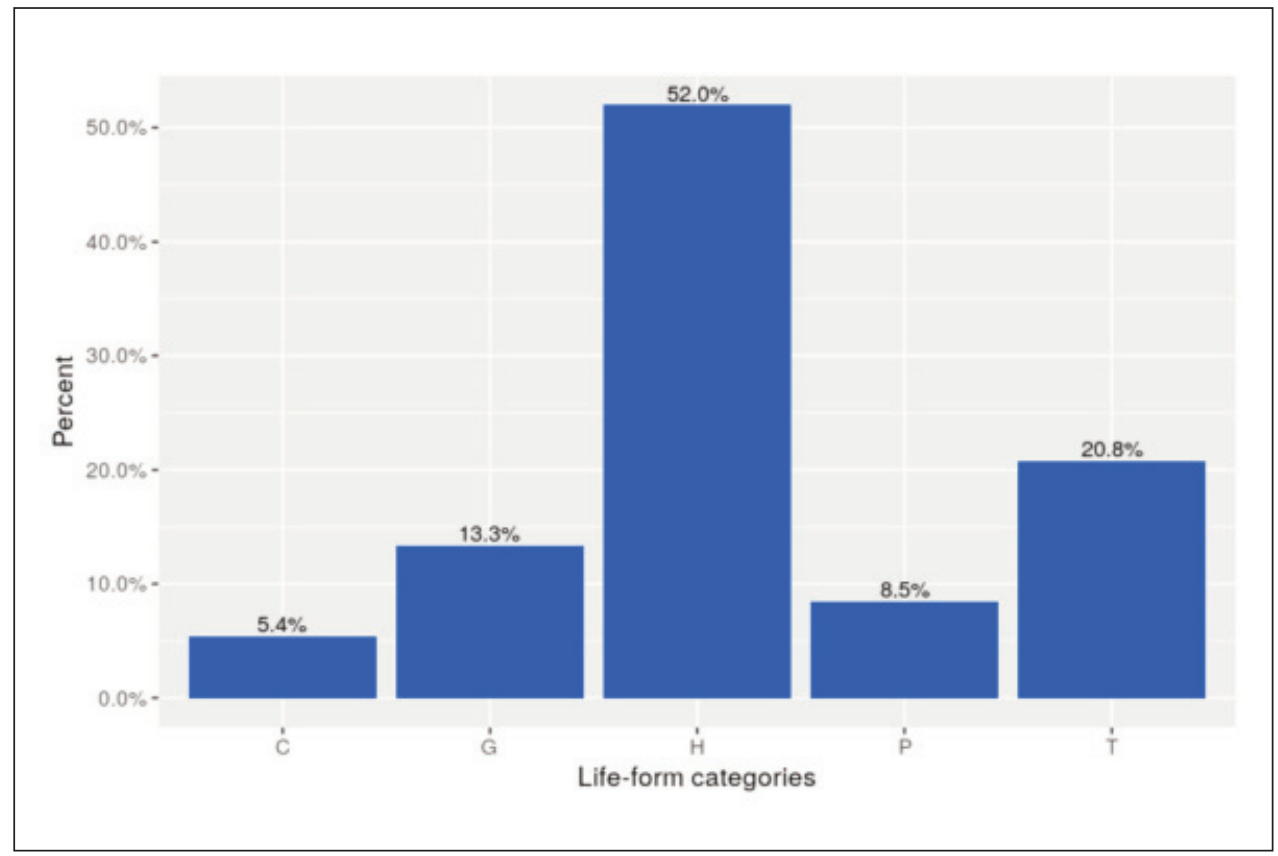

Fig. 3. Life-form spectrum of the vascular flora of Mt Tzena. P: Phanerophytes, C: Chamaephytes, H: Hemicryptophytes, G: Geophytes, T: Therophytes. 
Table 2. Chorological spectrum of the vascular flora of Mt. Tzena. The 21 chorological categories are classified into 5 wider chorological groups.

\begin{tabular}{|c|c|c|c|c|c|c|c|}
\hline & & of taxa & $\%$ & & & Nr. of taxa & $\%$ \\
\hline Widespread & & 634 & 50.76 & Mediterranean & & 326 & 26.10 \\
\hline $\begin{array}{l}\text { European-SW } \\
\text { Asian }\end{array}$ & EA & 278 & 22.26 & Mediterranean & $\mathrm{Me}$ & 142 & 11.37 \\
\hline Euro-Siberian & ES & 110 & 8.81 & $\begin{array}{l}\text { Mediterranean- } \\
\text { European }\end{array}$ & $\mathrm{ME}$ & 121 & 9.69 \\
\hline European & $\mathrm{Eu}$ & 92 & 7.37 & $\begin{array}{l}\text { Mediterranean- } \\
\text { SW Asian }\end{array}$ & MS & 40 & 3.20 \\
\hline Paleotemperate & $\mathrm{Pt}$ & 62 & 4.96 & E Mediterranean & EM & 18 & 1.44 \\
\hline Cosmopolitan & Co & 31 & 2.48 & $\begin{array}{l}\text { Mediterranean- } \\
\text { Atlantic }\end{array}$ & MA & 5 & 0.40 \\
\hline Circumtemperate & $\mathrm{Ct}$ & 28 & 2.24 & Balkan & & 275 & 22.02 \\
\hline Boreal & Bo & 15 & 1.20 & Balkan & $\mathrm{Bk}$ & 162 & 12.97 \\
\hline Arctic-Alpine & AA & 12 & 0.96 & Balkan-Anatolian & BA & 61 & 4.89 \\
\hline $\begin{array}{l}\text { Subtropical- } \\
\text { Tropical }\end{array}$ & ST & 5 & 0.40 & Balkan-Italian & BI & 33 & 2.56 \\
\hline Irano-Turanian & IT & 1 & 0.08 & $\begin{array}{l}\text { Balkan-C } \\
\text { European }\end{array}$ & $\mathrm{BC}$ & 20 & 1.60 \\
\hline Alien & & 7 & 0.56 & Endemic & $\mathrm{Gr}$ & 7 & 0.56 \\
\hline Total & & & & & & 1249 & 100.00 \\
\hline
\end{tabular}

Endemism - The Greek endemic vascular flora of Mt Tzena consists of 7 taxa. From the Greek endemics, Allium macedonicum Zahar., Laserpitium siler subsp. leave (Halácsy) Hartvig, Paronychia albanica subsp. graeca Chaudhri, Satureja montana subsp. macedonica (Formánek) Baden and Teucrium montanum subsp. helianthemoides (Adamovic) Baden are found almost exclusively on calcareous rocks while Dianthus corymbosus Sm. and Scilla subnivalis (Halácsy) Speta can be found on both calcareous and siliceous ground. The Balkan endemics (Bk) is the richest category of endemics in the flora of $\mathrm{Mt}$ Tzena with 162 taxa, followed by the sub-Balkan endemics (BA, BI, BC) with 114 taxa.

Range-restricted plants - Among the Greek and Balkan endemics found on Mt Tzena, there is a considerable amount of narrow (single-area) endemic taxa, distributed in the central Balkan area (i.e. northern Greece, Bulgaria, Albania, North Macedonia, Montenegro, southern Serbia, southern parts of Bosnia \& Herzegovina and Croatia). Narrow endemism in the mountains of northern Greece is often underestimated, as taxa occurring in small areas on both sides of the border with neighbouring countries have been simply classified as Balkan endemics. The concept of range-restricted taxa (Dimopoulos \& al. 2013) was used here to evaluate the local character and uniqueness of Tzena's flora.

In the vascular flora of Mt Tzena participate 62 range-restricted taxa. Among them can be found some very narrow endemic taxa with a restricted distribution in a few localities of NC Greece and North Macedonia (Achillea ageratifolia subsp. aizoon (Griseb.) Heimerl, Campanula formanekiana Degen \& Dörfl., Centaurea grbavacensis (Rohlena) 
Stoj. \& Acht., Stachys horvaticii Micevski and Viola frondosa (Velen.) Hayek) or NC Greece and Serbia (Ramonda nathaliae Pančić \& Petrovič).

\section{Conclusions}

Mt Tzena, despite its small area, presents a high diversity in vascular plants. The flora of the mountain is made up of 1254 taxa specific and subspecific. A total number of 858 vascular plants are recorded for the first time from the study area. Although Greek endemics represent a very small proportion of the total flora $(0.56 \%)$, Mt Tzena is very reach in Balkan endemics (162 taxa, $13 \%$ of the flora) and narrow endemic plants (62 taxa, $\sim 5 \%$ of the flora). Hemicryptophytes and therophytes are the most abundant plant life forms, while the most abundant chorological category consists of the widespread European-SW Asian plants.

\section{Acknowledgements}

We are grateful to Dr. Hildemar Scholz for verifying and identifying specimens of the genus Festuca, Koeleria and Poa. We would also like to thank Günter Gottschlich and Matthias Erben for verifying and identifying specimens of the genus Hieracium and Viola respectively. Special thanks go to Dr. Thomas Raus for verifying and identifying specimens of various genera.

\section{References}

Bancheva, S. T. \& Raimondo, F. M. 2003: Biosystematic studies of seven Balkan species from genus Cyanus (Compositae). - Bocconea 16: 507-527.

Beck, H. E., Zimmermann, N. E., McVicar T. R., Vergopolan, N., Berg, A. \& Wood, E. F. 2018: Present and Future Köppen-Geiger Climate Classification Maps at 1-Km Resolution. - Sci. Data 5: 180214. https://doi.org/10.1038/sdata.2018.214

Biel, B. \& Tan, K. 2008: Reports 2-17. [In: Vladimirov, V., Dane, F. \& Tan, K. (eds), New floristic records in the Balkans: 8]. - Phytol. Balcan. 14(2): 291-304.

Chasapis, M., Theodoropoulos, K. \& Eleftheriadou, E. 2013: Vegetation Mapping of Mt. Tzena (N. Greece). - Pp. 21-29 in: Proccedings of the $16^{\text {th }}$ Congress of the Hellenic Forestry Society. Thessaloniki.

Chasapis, M. 2017: The flora and the vegetation of Mount Tzena. - PhD Thesis, Aristotle University of Thessaloniki, Thessaloniki.

Chasapis, M., Samaras, D. A., Theodoropoulos, K., Eleftheriadou, E. \& Tan, K. 2019: Reports 1024. [In: Vladimirov, V., Aybeke, M., Matevski, V. \& Tan, K. (eds), New floristic records in the Balkans: 39]. - Phytol. Balcan. 25(2): 204-207.

Dimitrellos, G. \& Christodoulakis, D. 1995: The Flora of Mount Timfristos (NW Sterea Ellas, Greece). - Fl. Medit. 5: 9-51.

Dimopoulos, P., Raus, T., Bergmeier, E., Konstantinidis, T., Iatrou, G., Kokkini, S., Strid, A. \& Tzanoudakis, D. 2013: Vascular plants of Greece: An annotated checklist. - Berlin \& Athens.

—, Raus, T., Bergmeier, E., Constantinidis, T., Iatrou, G., Kokkini, S., Strid, A. \& Tzanoudakis, D. 2016: Vascular plants of Greece: An annotated checklist. Supplement. - Willdenowia 46: 301347. https://doi.org/10.3372/wi.46.46303 
Ellenberg, H. \& Mueller Dombois, D. 1967: A key to Raunkiaer plant life forms with revised subdivisions. Ber. geobot. Inst. eidg. Tech. - Hochschule Rubel 37: 56-73.

Emberger, L. 1966: Reflexions sur le spectre biologique de Raunkiaer. - Bull. Soc. Bot. France 113(suppl. 2): 147-156.

Font, M., Garcia-Jacas, N., Vilatersana, R., Roquet, C. \& Susanna, A. 2009: Evolution and biogeography of Centaurea section Acrocentron inferred from nuclear and plastid DNA sequence analyses. - Ann. Bot. 103: 985-997. https://doi.org/10.1093/aob/mcp022

Galeos, A., Karfakis, I. \& Fotiadis A. 1996: Geological Map of Greece 1:50000 - Sheet PROMAHI. - Athens.

Gonzalo-Estébanez, R. 2013: Taxonomía y sistemática de Stipa Sect. Stipa L. (Poaceae) y grupos afines. - Madrid.

Gottschlich, G. \& Schuler, A. 2011: Pilosella hypeurya (Peter) Soják. [In: Greuter, W. \& Raus, T. (eds) Med-Checklist Notulae, 30]. - Willdenowia 41: 316.

Jordanov, D., Kitanov, B., Valeu, S., Kozuharov, S. I., Kuzmanov, B. A. \& Valev, V. (eds) 1963-1995: Flora reipublicae popularis bulgaricae, 1-10. - Sofia.

Kučera, J., Lihová, J. \& Marhold, K. 2006: Taxonomy and phylogeography of Cardamine impatiens and C. pectinata (Brassicaceae). - Bot. J. Linn. Soc. 152: 169-195. https://doi.org/10.1111/j.1095-8339.2006.00559.x

Mauridis, A., Mataragas, D. \& Karfakis, I. 1982: Geological Map of Greece 1: 50000 - Sheet SKRA. - Athens.

Melzheimer, V. \& Greuter, W. 1979: Über zwei bemerkenswerte Arten der Gattung Silene (Caryophyllaceae) aus Nord-Griechenland. - Willdenowia 8: 613-623.

Parent, G. H 2005: Données floristiques inédites sur les montagnes grecques. - Syst. Geogr. Pl. 75: 195-238.

Pignatti, S. 1982: Flora d' Italia, 1-3. - Bologna.

Schuler, A. 2004: Charakterarten mitteleuropäischer Pflanzengesellschaften an ihrer Verbreitungsgrenze in Griechenland: eine Studie zum ökologischen und syntaxonomischen Verhalten am Arealrand. - Bot. Chron. 17: 1-168.

Snogerup, S. \& Snogerup, B. 2001: Bupleurum L. (Umbelliferae) in Europe 1. The annuals, B. sect. Bupleurum and sect. Aristata. - Willdenowia 31: 205-308. https://doi.org/10.3372/wi.31.31201

Strid, A. \& Papanicolaou, K. 1981: Floristic notes from the mountains of Northern Greece Materials for the Mountain Flora of Greece, 7. - Nord. J. Bot. 1: 66-82. https://doi.org/10.1111/j.17561051.1981.tb01037.x

— \& Franzen, R. 1982: New floristic records from the mountains of Northern Greece. - Willdenowia 12: 9-28.

- (ed.) 1986: Mountain Flora of Greece, 1. - Cambridge.

— \& Tan, K. (eds) 1991: Mountain Flora of Greece, 2. - Edinburgh.

— \& - (eds) 1997: Flora Hellenica, 1. - Königstein.

— \& - (eds) 2002: Flora Hellenica, 2. - Ruggell.

— \& - 2017: Recent progress in plant taxonomy and floristic studies in Greece. - Bot. Serbica 41(2): 123-152.

Tan, K., Vold, G. \& Sfikas, G. 2006: Reports 88-95. [In: Vladimirov, V., Dane, F., Nikolić, T., Stevanović, V. \& Tan, K. (eds), New floristic records in the Balkans: 2]. - Phytol. Balcan. 12(2): 296-297.

Tiniakou, A. 1991: Cytogeographical Studies on Some Species of Viola Sect. Viola (Violaceae) from Greece. - Willdenowia 20: 153-158.

Tutin, T. G., Burges, N. A., Chater, A. O., Edmondson, J. R., Heywood, W. H., Moore, D. M., Valentine, D. H., Walters, S. M. \& Webb, D. A. (eds) 1993: Flora Europaea, 1. - Cambridge. 
—, Heywood, V. H., Burges, N. A., Moore, D. M., Valentine, D. H., Walters, S. M. \& Webb, D. A. (eds) 1968-1980: Flora Europaea, 2-5. - Cambridge.

Vlachos, A., Georgiadis, T. \& Tiniakou, A. 2009: Floristic Research of the mountains of Sterea Hellas (Central Greece) and their affinities with mountains of Peloponissos. - J. Biol. Res.Thessalon. 12: 193-209.

Voliotis, D. 1983: Zur Flora des Tzena - Gebirges in Nord-Griechenland. - Acta Bot. Croat. 42: 157172.

- 1986: Historical and environmental significance of the Yew (Taxus baccata L.). - Israel J. Bot. 35: 47-52.

Zohary, M. \& Heller, D. 1984: The genus Trifolium. - Israel.

Addresses of the authors:

Minas Chasapis ${ }^{1}$, Dimitrios A. Samaras ${ }^{2 *}$, Konstantinos Theodoropoulos ${ }^{3}$ \& Eleni Eleftheriadou ${ }^{2}$,

${ }^{1}$ Forest Office of Aridaia, Xenitidi \& Ermou Str. 5, 58400 Aridaia, Greece.

${ }^{2}$ Department of Forestry and Natural Environment Management, Agricultural University of Athens, Dimocratias 3, GR-36100, Karpenisi, Greece.

${ }^{3}$ Aristotle University of Thessaloniki, School of Forestry and Natural Environment, Laboratory of Forest Botany - Geobotany, P.O. Box 270, University Campus, GR54124, Thessaloniki, Greece.

*Corresponding author: Dimitrios A. Samaras, E-mail of mail@dimitriossamaras.net 
